3. Develop methods/measures/tools that permit individual resident advancement instead of solely using block/time criteria for advancement.

4. Define criteria for developing tracks, focused experiences and fourth year concentrations.

5. Change the predominant measurement parameters from number of patients seen or months experienced to competencies achieved.

6. Advocate that residencies ensure that residents participate in research programs that produce new information about caring for patients - instead of simple literature reviews.

These 6 concerns are content areas that have potential solutions. However, none of these concerns can be effectively resolved unless the RRC requirements are significantly simplified and shortened. ADFM in collaboration with AFMRD could draft an example of a shortened/focused RRC requirements. However, major revision of the RRC requirements with simplification and brevity as a goal will not occur without developing a 'new relationship' between ADFM, AFMRD, and the RRC. These relationships must be established by structured communication. First, communication between ADFM and the AFMRD should occur regularly by having representation at each other's appropriate meetings. Second, ADFM should regularly invite the chair of the RRC to give a report at the annual winter meeting. Third, the ADFM Residency Committee should develop principles for innovation and research, in collaboration with AFMRD, and request that they become part of future RRC requirements. Lastly, ADFM should develop educational sessions on residency innovation, research in residencies and competency-based education for presentation at annual ADFM meetings.

ADFM can see the RRC as an obstructive force that needs to be moved out of the way or the RRC may be seen as a latent agent of change that needs better communication and proactive assistance in order to move the discipline into the future. The latter approach is likely to get better results in a more timely manner.

Alan K. David, MD, and the Association of Departments of Family Medicine

\footnotetext{
References

1. Pugno PA, Epperly TD. Residency Review Committee for Family Medicine: an analysis of program citations. Fam Med. 2005;37(3):174-177.

2. Accreditation Council for Graduate Medical Education (ACGME). ACGME Program Requirements for Graduate Medical Education in Family Medicine. http://www.acgme.org/acWebsite/downloads/RRC_ progReq/120pr07012007.pdf.

3. Martin JC, Avant RF, Bowman MA, et al. The future of family medicine: a collaborative project of the family medicine community. Ann Fam Med. 2004;2(Suppl 1):S3-S32.
}

4. The Residency Assistance Program - Criteria for Excellence. $6^{\text {th }}$ ed. Leawood, Kan:RAP Project Board; 2006.

5. TransforMed. P4: Preparing the Personal Physician for Practice. http://www.transformed.com//p4.cfm.

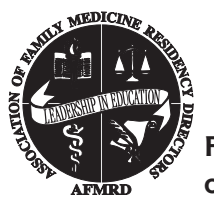

From the Association of Family Medicine Residency Directors

Ann Fam Med 2007;5:470-471. DOI: 10.1370/afm.768.

\section{BUILDING THE FOUNDATION OF A BETTER HEALTHCARE SYSTEM: FOR THE COMMON GOOD}

Has a fellow traveler on an airplane ever asked you what it is you do? When someone asks me the "What do you do?" question, I tell them, "I'm building the foundation of a better healthcare system." I believe it is the destiny of family medicine to be the foundation of a new system of healthcare for the common good of the American people. I believe that our discipline was created for this moment in time when all the interested parties in the business of healthcare are looking out for their own self-interests and not the common good. As natural servant leaders, family physicians work close enough to the people to care and work for the common good. As the trainers of the next generation of family physicians, we are building the foundation of a better health care system.

I envision a system of healthcare with a medical home for all Americans. These medical homes will be created, sustained, and staffed by family physicians and our primary care colleagues. The American Academy of Family Physicians, the American Academy of Pediatrics, the American College of Physicians, and the American Osteopathic Association have published an excellent description of the medical home entitled "Joint Principles of the Patient-Centered Medical Home." I encourage you to read these joint principles as you build the medical homes in your practice. When you build a good medical home you are building the foundation of a better health care system. The Commonwealth Fund 2006 Health Care Quality Survey provides new evidence of the value of medical homes. ${ }^{2}$ Promising findings from this survey are that adults who have a medical home have improved access to care, higher rates of preventive screening, are better prepared to self-manage their hypertension, and racial disparities in access to and quality of care are reduced or eliminated. ${ }^{2}$

I believe that the medical home is the unit of primary care for this country, and that we are approach- 
ing the tipping point in the rest of the country coming to the same conclusion. What are the training implications of this? Our family medicine centers must be medical homes that truly offer an apprenticeship experience to learners at all stages from premedical students, to medical students, to residents, to fellows, to faculty. We must ensure that our residencies train our residents so that they will thrive in the medical homes of the future. Is it time for all medical students to receive training in a medical home, so they understand the foundation upon which the health care system will be built? Is it time to require a continuity of care experience in a medical home as a core competency to graduate from medical school?

One problem with the medical home model is that you can't fund it on $\mathrm{E}$ and $\mathrm{M}$ codes alone. It requires additional reimbursement that pays for care coordination and management that occurs outside of the office visit.

Who deserves extra reimbursement as a medical home? There is an opportunity for practices to become certified as medical homes by the National Committee for Quality Assurance (NCQA) with their Physician Practice Connections program. I predict that in the near future this certification will enable medical homes to receive enhanced practice revenue. This revenue will allow us to continue the work that we do every day that just isn't paid by office visits, such as telephone management, case and disease management, electronic medical record costs, and continuous quality improvement to name a few. A number of pilot programs are underway linking the Physician Practice Connections certification with enhanced revenue. If you review the Physician Practice Connections Standards of the NCQA (Table 1) most family medicine teaching practices have already put many of the requirements into place.

We are a patient-care based specialty and our train-

\section{Table 1. NCQA Practice Connection Standards}

Access and communication for patients

Patient tracking and registry functions

Care Management

Patient self-management support

Electronic prescribing

Test and referral tracking

Performance reporting and improvement

Interoperability of electronic systems

From the National Committee for Quality Assurance. 2006 Standards and Guidelines for Physician Practice Connections. 2006. http://web.ncqa.org/ tabid/141/Default.aspx.

ing needs to maintain that emphasis. Our job is to train our residents as the clinical equivalent of pleuri-potential stem cells. After residency, family physicians can differentiate into whatever their position or community requires. But, at the core, they were trained in the basic principles of family medicine in a medical home. I believe it is the destiny of family medicine to be the foundation of a better healthcare system for America. We are needed ... for the common good.

Mark Robinson, MD

President, AFMRD

\section{References}

1. American Academy of Family Physicians. Joint statement on the Principles of the Patient-Centered Medical Home. June 24, 2007. http://www.aafp.org/online/etc/medialib/aafp_org/documents/policy/fed/jointprinciplespcmh0207.Par.0001.File.tmp/ 022107medicalhome.pdf.

2. Beal AC, Doty MM, Hernandez SE, Shea KK, Davis K. Closing the Divide: How Medical Homes Promote Equity in Health Care: Results from The Commonwealth Fund 2006 Health Care Quality Survey. The Commonwealth Fund; 2007.

3. National Committee for Quality Assurance. 2006 Standards and Guidelines for Physician Practice Connections. 2006. http://web. ncqa.org/tabid/141/Default.aspx. 